\title{
Teaching
Methods
}

\section{Course Content and Attitudes Toward Instructional Multimedia Use in Nursery Management and Production Courses in the United States}

\author{
Amy N. Wright ${ }^{1,4}$, James A. Robbins ${ }^{2}$, and Mengmeng $\mathrm{Gu}^{3}$
}

AdDITIONAL INDEX wORDs. virtual, online, distance education, web-based, field trips, technology, video

SuMMARY. An online survey was conducted to gain information about nursery management and production (NMP) course content and enrollment, attitudes regarding the use of multimedia resources in the classroom, and opinions about the use of virtual field trips to supplement or replace traditional field trips. Results reflected current organizational and curriculum changes within colleges of agriculture that have impacted traditional horticulture courses such as NMP and in many cases have resulted in the merging of NMP courses with other courses such as greenhouse or garden center management. The number of departments with "horticulture" in the department name was similar to the number of departments with "plant science" in the department name (and not "horticulture"). The five topics covered most frequently included container production, container substrates, fertility, field production, and pot-in-pot production. Most of the respondents indicated that the NMP course in their department included at least one field trip. The top criteria used for selecting field trip locations included type of nursery, distance, innovation, reputation, and the number of aspects that could be viewed. Accessibility and distance to nurseries were listed as primary limitations for providing comprehensive field trips. Most respondents currently use multimedia resources in courses other than NMP, and a majority of respondents indicated that multimedia resources such as DVDs or web-based videos would be valuable for supplementing instruction in NMP, particularly for aspects not observed during field trips.

We thank Lisa Ferris, Program and Staff Development, and Wilma Lewis, Information Technology, with the Cooperative Extension Service of the University of Arkansas for their valuable assistance in formulating and implementing this survey.

${ }^{1}$ Department of Horticulture, Auburn University, 101 Funchess Hall, Auburn, AL 36849

${ }^{2}$ Department of Horticulture, University of Arkansas CES, Little Rock, AR 72204

${ }^{3}$ Department of Plant and Soil Sciences, Mississippi State University, MS 39762

${ }^{4}$ Corresponding author. E-mail: awright@auburn.edu.
$\mathrm{T}$ he nursery industry is a key segment of U.S. agriculture with an estimated wholesale value of almost \$13 billion in 2006 (Jerardo, 2007). In 2006, the 17 largest nurseryproducing states in terms of gross sales accounted for 471,106 acres of production and employed 112,672 workers (U.S. Department of Agriculture, 2007). In 2007, the value of greenhouse and nursery crops in Oregon alone was estimated to be over \$1 billion (O'Connor, 2008). To expand or even maintain this key segment of agriculture will require well-trained employees. One source of qualified employees in the nursery industry is students at land grant universities. In the past, many of the horticulture and plant science programs at these institutions have offered a class in nursery management and production. However, availability of qualified faculty, integration of departments, and cutbacks in horticulture programs may have led to a reduction in the number of nursery management and production (NMP) courses being offered in the United States.

Nursery management and production involves an understanding of fundamental principles as well as practical operations. A traditional NMP course includes classroom lectures and observation of actual production systems and operations. Ideally, an NMP course includes field trips to nurseries to view various production systems in situ. The benefit of visual and on-site experiences for enhanced learning is well documented (Brunner, 1961; Krepel and DuVall, 1981; Larkin-Hein and Zollman, 2000). In many cases, however, budget constraints, time limits, transportation logistics, and limited access to qualified nurseries may make scheduling field trips a challenge. Recently, a set of instructional DVDs were produced by horticulture educators for use in teaching greenhouse production courses (Harkess et al., 2007). Each instructional unit in the DVD set focused on one individual greenhouse production business and its operations. In lieu of nursery site visits, it is possible that instructors could use multimedia tools (e.g., DVDs) for instructional purposes. Lin and Fox (1999) showed that videos can be highly motivational compared with more traditional

\begin{tabular}{llll}
\hline $\begin{array}{l}\text { Units } \\
\begin{array}{l}\text { To convert U.S. to SI, } \\
\text { multiply by }\end{array}\end{array}$ & U.S. unit & SI unit & $\begin{array}{l}\text { To convert SI to U.S., } \\
\text { multiply by }\end{array}$ \\
\hline 0.4047 & acre(s) & ha & 2.4711 \\
1.6093 & mile(s) & $\mathrm{km}$ & 0.6214
\end{tabular}


methods of instruction. Although some multimedia materials are available for individual topics in nursery production, they are generally expensive and often contain dated material. For example, American Nurseryman (Chicago) used to offer a two-videotape series produced in 1992 for $\$ 100$ but does not currently offer any DVDs (American Nurseryman, 2010). San Luis Video Publishing (Los Osos, CA) offers a small number of DVDs on greenhouse management, each $\approx 30$ min long and costing $\$ 95$ (San Luis Video Publishing, 2010). Insight Media (New York) offers a DVD on container-grown plants. Unfortunately, this DVD on a single topic is from 1990, is only $26 \mathrm{~min}$ long, and costs \$129 (Insight Media, 2010).

To date, there has not been a survey of horticulture and related departments in the United States to gather information on course content and the current use of field trips and multimedia tools in NMP courses. The current lack of instructional multimedia resources for NMP courses coupled with the availability of technology and the likely ease of incorporating such resources at most universities suggests that there may be a need and/or desire for virtual field trips to supplement current field trips and classroom instruction. Possible shifts in departmental focus (from applied to basic), merging of departments (personal observation), and the number of qualified faculty could affect traditional NMP instructional strategies. Therefore, the objective of this study was to gain information about NMP course content and enrollment, attitudes regarding the use of multimedia resources in the classroom, and opinions about the use of virtual field trips to supplement or replace traditional field trips.

\section{Materials and methods}

A survey targeted at instructors of courses that cover topics in NMP was designed in Fall 2008 with the assistance of an instructional design specialist at the University of Arkansas Cooperative Extension Service. The online survey was created using Perseus SurveySolutions (Perseus Development, Braintree, MA) and hosted on the University of Arkansas Cooperative Extension Service web site. In addition to collecting information such as department name, frequency of course offering, and typical enrollment, the survey asked questions regarding topics covered, field trip details, use of multimedia resources, and limitations in providing instruction. The survey contained a variety of question formats including openended (e.g., how many students are enrolled), binomial selection (yes/no), single selection (select one from a list), multiple selection (select all that apply), and ranking or rating. Most questions provided the opportunity for the respondent to indicate additional responses not specifically addressed or included in the question as well as provide optional written comments.

An e-mail request to complete the survey was sent from the American Society for Horticultural Science (ASHS) to departments on the ASHS ADMIN listserv $(\mathrm{n}=61)$ on 12 Nov. 2008. A second e-mail was sent to this same group of administrators on 21 Nov. 2008 because the University of Arkansas Cooperative Extension Service server initially was not accepting submissions (responses), so the ASHS AMIN list was recontacted once that issue had been resolved. The authors developed an additional survey list based on 1864 and 1890 land grant institutions not included on the original ASHS ADMIN list. An e-mail request was sent by the authors to this group $(\mathrm{n}=36)$ on 20 Nov. 2008. In total, 97 institutions were contacted and asked to complete the survey. On 2 Jan. 2009, institutions that had not responded to the online survey were contacted again by the authors by e-mail and asked to complete the survey by 16 Jan. 2009. In all cases, administrators were asked to forward the survey to the most "appropriate" faculty member in their department (i.e., one who teaches or has taught nursery management). Using Perseus SurveySolutions software, survey responses were compiled and summarized on 23 Jan. 2009, and frequency data were generated to provide percent of total sample for responses to all questions except ranking or rating questions. Means separation of ranked and rated responses were performed using least significant difference procedures at $P=0.05$ (SAS Version 9.1; SAS Institute, Cary, NC).

\section{Results}

RESPONDENT INFORMATION AND COURSE ENROLlment. Fifty-three of the 97 institutions that were contacted completed the survey, representing a $55 \%$ response rate. Only one reply was received per responding institution. Institutions responding represented 42 states. Among respondents, 21 department names contained the word "horticulture," and 19 department names contained the words "plant science" (and not "horticulture"). When offered, NMP is primarily undergraduate level and tends to be upper level (58\%). Some institutions (18\%) offer it as a graduate-level course, likely crosslisted with an undergraduate version. The course was offered every year $(44 \%)$ or every other year (40\%). Fifty-six percent of responding institutions indicated the course was required by the department. Typical enrollment in the course was 25 students or fewer at all but three institutions. Enrollment in most $(60 \%)$ courses was between 10 and 20 students.

Course justification and CONTENT. Overall, 45 institutions are currently offering (37) or have offered (eight) NMP. One hundred percent of respondents at institutions that currently offer NMP indicated that the course helps prepare students for careers in nursery management and production. Additionally, 65\% of these respondents also indicated that the course played a role in developing relationships between students and potential employers and industry professionals as well as between the department and industry professionals (70\%). Forty-six percent of these respondents indicated that the course provided foundational concepts that could be applied in other courses, likely because of the broad range of topics covered in NMP. When presented with a list of topics associated with NMP (Table 1) and asked to select which ones were covered at the respondent's institution, the top five selected included: "container production" (100\%), "container substrates" (100\%), "fertility" $(97 \%)$, "field production" (97\%), and "pot-in-pot production" (92\%). "International issues" were covered least frequently $(32 \%)$. When given the opportunity to list "other" topics that were covered by the course but not included in our list, nine respondents indicated business-related topics (e.g., finance, planning, business planning, and accounting). 
Table 1. Topics in nursery management and production (NMP) courses and the frequency with which those topics are covered in current NMP courses. ${ }^{z}$

\begin{tabular}{lc}
\hline Topic & Frequency (\%) \\
\hline Container production & 100 \\
Container substrates & 100 \\
Fertility & 97 \\
Field production & 97 \\
Pot-in-pot production & 92 \\
Winter protection & 89 \\
Irrigation & 84 \\
Potting & 78 \\
Pest management & 78 \\
Bareroot harvesting/ & 78 \\
$\quad$ grading/storage & \\
Marketing & 73 \\
Shipping & 70 \\
Propagation & 70 \\
Innovation/ & 70 \\
$\quad$ mechanization & \\
International issues & 32 \\
Other & 30 \\
\hline
\end{tabular}

${ }^{2}$ Responses are included from institutions that currently offer an NMP course ( $n=37$ ).

y Other responses included business, finance, water quality, and plant breeding.

In instances in which the course had previously been offered by a department but had been discontinued, respondents indicated that this was the result of either the lack of qualified faculty to teach the course $(25 \%)$ or that enrollment in the course tended to be low (38\%). One written comment indicated that as departments begin to align their focus more with genetics and biotechnology programs, some of the more traditional horticulture courses are being eliminated. Other respondents indicated they were not able to offer NMP as a result of changes in curriculum, disinterest, or shrinking faculty numbers. The time since a course in NMP was eliminated by a department ranged from 1 to 12 years. Half of those institutions had discontinued the course within the past 1 to 5 years and the other half within the past 9 to 12 years. At institutions where a course in NMP is not currently offered, two respondents indicated plans to offer the class again in the future. The primary reasons responding institutions did not plan to offer the course in the future were the same as those reasons listed for discontinuing the course in the first place. Nine of the responding institutions have never offered NMP.
Field TRIPS. Most (82\%) of the respondents indicated the NMP course in their department included at least one field trip. Typically $(78 \%)$ $4 \mathrm{~d}$ or fewer were dedicated to field trips, and generally (76\%) field trips visited four nurseries or fewer during the course. Transportation was almost always (94\%) provided for students on field trips. The shortest round-trip distance traveled on a single field trip was typically $(83 \%) 50$ miles or less. The longest round-trip distance was usually (71\%) less than 250 miles with $35 \%$ of respondents indicating the longest field trip was less than 80 miles and $57 \%$ indicating they traveled less than 180 miles. Because these are round-trip distances, responses suggest that field trips are typically to nurseries within an institution's local region. For those institutions that did not offer field trips with the course, there was no single factor that was consistently identified as preventing them from doing so. Instead, it appeared to usually be a combination of factors that primarily included cost, distance, transportation logistics, and time. The survey also attempted to evaluate which criteria were used when choosing locations for field trips by asking respondents to rate the relative importance of several criteria. Based on ratings assigned by respondents, a weighted average was calculated for all criteria (Table 2). The most important factors were (in descending order): "type of nursery," "distance to nursery," "reputation," "innovative techniques," and "number of aspects viewed." The "length of time in business" was selected least frequently. When asked what topics students were not able to observe during field trips, "international issues" (54\%), "bareroot harvesting/grading/storage" $(38 \%)$, and "innovation/mechanization" (30\%) topped the response list. When asked what prevents an institution from being able to observe these topics on a field trip, the number one response $(46 \%)$ was "not accessible/too far away." One-third of respondents $(32 \%)$ also indicated limited time was available for field trips. The inability to view topics such as international issues, bareroot harvesting/grading/storage, and innovation/mechanization indicates the need for an alternative method to present this information. Topics such
Table 2. Criteria used by respondents when choosing field trip locations for nursery management and production (NMP) courses. ${ }^{\mathrm{z}}$

\begin{tabular}{|c|c|}
\hline Criterion & $\begin{array}{c}\text { Avg rating } \\
(1 \text { to } 5 \text { scale })^{\mathrm{y}}\end{array}$ \\
\hline Type of nursery & $4.28 \mathrm{a}^{\mathrm{x}}$ \\
\hline Reputation & $4.11 \mathrm{ab}$ \\
\hline Innovative techniques & $4.08 \mathrm{~b}$ \\
\hline Distance to nursery & $4.06 \mathrm{~b}$ \\
\hline Product quality & 4.0 \\
\hline $\begin{array}{l}\text { Number of aspects } \\
\text { viewed }\end{array}$ & $4.00 \mathrm{~b}$ \\
\hline Scope of operations & $3.72 \mathrm{c}$ \\
\hline $\begin{array}{l}\text { Transportation } \\
\text { availability/cost }\end{array}$ & $3.67 \mathrm{c}$ \\
\hline Size of nursery & $3.33 \mathrm{~d}$ \\
\hline $\begin{array}{l}\text { Length of time in } \\
\text { business }\end{array}$ & $2.81 \mathrm{e}$ \\
\hline \multicolumn{2}{|c|}{$\begin{array}{l}{ }^{2} \text { Responses are included from institutions that cur- } \\
\text { rently offer an NMP course }(\mathrm{n}=37) \text {. } \\
{ }^{y} 5=\text { highest priority and } \mathrm{l}=\text { lowest priority. } \\
{ }^{\mathrm{x}} \mathrm{Mean} \text { separation by least significant difference pro- } \\
\text { cedures at } P=0.05 \text { (SAS Version 9.1; SAS Institute, } \\
\text { Cary, NC). }\end{array}$} \\
\hline
\end{tabular}

as "container production," "irrigation," and "potting" appear to be easily covered in current field trips because no institution reported not being able to observe these aspects. Two respondents indicated in written comments that they could see all of the aspects listed.

When asked what nurseries the respondents would like to visit on field trips if funding or other factors were not limiting, the top five responses in descending order were: Monrovia Nursery in Azusa, CA (11); Bailey Nurseries in St. Paul, MN (nine); J. Frank Schmidt \& Son Co. in Boring, OR (six); Spring Meadow Nursery in Grand Haven, MI (five); and Iseli Nursery, Inc. in Boring, OR (four). Saunders Brothers in Piney River, VA (three) and Lancaster Farms in Suffolk, VA (three) were also mentioned. Hines Nurseries in Irvine, CA, which has historically been in the top five largest nurseries, was mentioned only once. Each respondent provided a list of nurseries that represented a wide geographic range, one which could not reasonably be visited by a single institution. Similarly, respondents were asked what states they would visit. The top five responses in order of decreasing preference were: Oregon (20), California (15), Washington (10), and Florida (nine); Tennessee, North Carolina, and Ohio tied for fifth with each state 
receiving six responses. Although Oregon, California, and Florida were not surprising, Washington, although included in the abbreviated Nursery Crops 2006 Survey (U.S. Department of Agriculture, 2007), ranks 14th in gross sales, 1lth in rank of number of producers, and 13th in a rank of nursery acreage. It is possible that the reputation of the tissue culture facilities at Briggs Nursery in Elma, WA, was a reason respondents indicated a desire to visit the state of Washington. Minnesota, which ranked sixth in our survey for a field trip destination, is not currently included in the Nursery Crops 2006 Survey (U.S. Department of Agriculture, 2007). Because Bailey Nurseries ranked second in field trip preferences in this survey, perhaps this is linked to the high ranking by survey respondents from Minnesota.

Multimedia Tools. To evaluate the use of technology in the classroom, respondents were asked about their use of multimedia resources in NMP courses. Only 11\% of respondents indicated that they did not use any multimedia tools to deliver or supplement course content in NMP. A substantial percentage of respondents indicated that they used DVDs (51\%) and web-based videos (42\%) in their NMP courses. Thirty-one percent of respondents replied that they still show videotapes in class. Respondents felt, however, that the adequacy $(56 \%)$ and availability (49\%) of existing NMP multimedia tools were limiting. The cost $(36 \%)$ of existing multimedia resources also limited use. In written comments, instructors mentioned that they also use web-based images and web sites in their class. One respondent indicated that they have attempted to record audiovisual footage of NMP operations and convert it to digital format, but stated that this has been extremely time-consuming and was almost too overwhelming for one person to tackle.

To determine if responses regarding multimedia use were unique to courses in NMP, respondents were asked the same questions regarding other university courses. In courses other than NMP, responses were similar in that instructors showed DVDs and web-based videos; however, the percentages of those using such resources were higher $(68 \%$ and $47 \%$, respectively). Like with NMP courses, instructors indicated that they still show videotapes in courses other than NMP (45\%). The higher frequency of incorporation of multimedia resources in courses other than NMP appeared to reflect the limited availability of adequate NMP multimedia resources. In fact, fewer respondents indicated the presence of limitations to using multimedia resources in courses other than NMP. Instead, the biggest limitation to incorporating multimedia resources into classroom instruction in courses other than NMP appeared to be lack of appropriate facilities $(44 \%)$. This is in contrast to responses regarding NMP courses in which only $7 \%$ of respondents indicated such a limitation. Blackboard (Washington, DC) or WebCT (owned by Blackboard) was used at $82 \%$ of respondents' institutions.

Respondents were asked for which topics in NMP they felt multimedia tools could be helpful in improving student understanding (Table $3)$. Forty percent or more of respondents indicated that innovation/ mechanization, bareroot harvesting/ grading/storage, field production, pot-in-pot production, shipping, and international issues were topics for which multimedia tools could improve instruction and student understanding. For all topics, at least $24 \%$ of respondents indicated multimedia tools would be helpful. Some respondents also listed additional topics (not mentioned in the question) for which multimedia tools could enhance instruction. These included site selection and layout, cover crops, soil management, and finances. Eightytwo percent of respondents indicated that a set of instructional DVDs would be helpful for providing instruction on all or some topics in NMP. Whereas $56 \%$ of respondents said that DVDs cannot substitute for field trips that they were able to take, $85 \%$ said that DVDs would be helpful in substituting for some or all of those that they could not take. Written comments provided by respondents regarding multimedia tools were overwhelmingly supportive. One exception was one respondent who indicated they did not feel comfortable using multimedia tools in any course.

\section{Discussion}

NMP covers a broad range of topics, many of which are unique to
Table 3. Topics in nursery management and production (NMP) courses and the frequency with which responding institutions indicated multimedia tools could significantly improve student understanding and learning for that topic. $^{z}$

\begin{tabular}{lc}
\hline Topic & Frequency (\%) \\
\hline $\begin{array}{l}\text { Innovation/ } \\
\quad \text { mechanization }\end{array}$ & 63 \\
$\begin{array}{l}\text { Bareroot harvesting/ } \\
\text { grading/storage }\end{array}$ & 50 \\
Field production & 48 \\
Pot-in-pot production & 44 \\
Shipping & 44 \\
International issues & 44 \\
Pest management & 39 \\
Marketing & 39 \\
Container production & 37 \\
Irrigation & 30 \\
Winter protection & 28 \\
Fertility & 28 \\
Container substrates & 26 \\
Propagation & 26 \\
Potting & 24 \\
Other & 17
\end{tabular}

${ }^{2}$ Responses are included from institutions that currently or used to offer an NMP course $(n=45)$.

this and related subject areas (e.g., greenhouse or plant propagation). Simply describing these aspects is not enough. Rather, the student must view live action or video images to fully grasp the nature of this industry's practices and operations. As would be expected, field trips are an important part of the instructional process in NMP courses. Economics and logistics limit the ability of instructors of NMP and related courses to provide comprehensive field trips, and even when trips to local nurseries are feasible, these frequently present only a fraction of the innovations, practices, and approaches to nursery production that are in use throughout the United States. Field trips inherently have limitations as noted by one of the respondents: "Field trips are better for providing overviews of nursery operations and allowing students to actually see what a nursery looks like rather than showing detailed images of all the individual aspects of nursery management/production. Short video footage segments can easily be incorporated into classroom lectures and can provide closeup images of specific components like fertilizer application, pruning, potting machines, etc. that may not 
be visible or accessible if simply driving around or walking through part of a nursery." In other words, the use of close-up video segments is extremely useful for illustrating certain techniques, which might not be able to be viewed in detail even with a nursery field trip. For example, the actual steps of budding or tissue culture may be difficult to observe on a field trip, but a video segment could be incorporated into a PowerPoint (Microsoft, Redmond, WA) slideshow to provide dramatic visual impact. This is supported by Gomez (2004) who, while studying the use of a video to teach T-budding in an introductory plant propagation course, reported that although students felt that the clarity of the faceto-face demonstration was better than the video presentation, student grades were higher for those who viewed the video versus the face-to-face demonstration. This is not meant to imply that instructors should abandon onsite nursery field trips in favor of showing videos. Spicer and Stratford (2001), surveying university students, concluded that although students were extremely positive about the potential of a virtual field trip to provide a valuable learning experience in a biology class, nearly all students were insistent that it could not, and should not, replace real field trips. Instead, videos could be used to augment traditional classroom, laboratory, and field trip activities.

Several studies have demonstrated the effectiveness of a video delivery format for use in instruction (Cofield, 2002; Corporation for Public Broadcasting, 1997; Migliacci, 2002; Sorrell and Cangelosi, 2002). Research on learning styles of students enrolled in agriculture indicated that they normally prefer more actionoriented, practical classes and that a multimedia component could add excitement to the curricula and help student retention and enrollment (Dyer and Osborne, 1996). Tignor et al. (2007) suggest that organizing instructional DVDs by topic is most helpful and makes it easier for an instructor to integrate video materials into classroom lectures and Internetbased resources into online delivery. This approach to information organization was repeated several times in written comments in which respondents indicated a preference for multimedia resources that would be arranged by topic. Respondents indicated that DVDs organized by content could more easily be integrated into existing course materials. Any video material developed for DVDs could also easily be converted to online formats and posted online in the form of downloadable podcasts, streaming videos, or YouTube (San Bruno, CA) videos. Although the use of podcasts to deliver instructional information is relatively new, there are examples of success in using this format to deliver educational information (Belanger, 2005; Chinney, 2006; Xie and $\mathrm{Gu}, 2007$ ). At least 12 land grant universities use podcasts to disseminate instructional and research-based agricultural information. These podcasts range from an individual episode on a specific topic (Mississippi State University) to weekly technical newsletters (Texas A\&M University). Recently, the development of iTunes U (Apple, Cupertino, CA) made it possible for over 20 institutions to post educational content in the form of podcasts, granting free access to these materials. YouTube is also used by universities to post instructional videos. Respondents indicated that videos related to NMP could also be used in other courses like plant propagation, fruit production, and arboriculture.

Eight written comments reflected the trend of department reorganization within colleges of agriculture at land grant institutions, one that often results in the merging of departments. In many cases this involves the creation of a plant sciences department, meaning traditional horticulture departments are not as common as they once were. This is reflected in the results of this survey in that the number of departments with "horticulture" in the department name was similar to the number of departments with "plant science" in the department name (and not "horticulture"). This is similar to results of a recent survey of undergraduate horticulture programs. Among the 22 survey participants, nine were from a department that contained the word "horticulture" in the name, whereas seven were from a department in which "plant science" (and not "horticulture") was part of the department name (Basinger et al., 2009). Current organizational and curriculum changes within colleges of agriculture have impacted traditional horticulture courses such as NMP, and in many cases these changes have resulted in discontinuing NMP courses or combining with courses such as greenhouse management/production, garden center management, arboriculture, or plant propagation. This does not appear to necessarily represent the preference or opinions of horticulture faculty. In Basinger et al. (2009), respondents were asked to identify and rank competencies they felt were important for undergraduate horticulture students. Based on the number of competencies identified in the survey, the topic of field and greenhouse management made up the largest single group of skills. This topic also received a $95 \%$ to $100 \%$ importance rating for including in a horticulture curriculum, indicating the continued value that faculty place on these topics.

Some departments also report switching the instructional focus in their department to more basic subjects such as plant breeding and genetics and eliminating applied courses such as NMP. This change in focus has led to a lack of faculty qualified to teach NMP and was frequently cited as a reason for eliminating the course or combining it with another course. One respondent did indicate that they had converted their NMP course to an online format. For those departments without faculty qualified to teach NMP, using online courses from other institutions may be the only way for those departments to offer NMP and/or related courses. The development of video-based multimedia resources for topics in NMP could be vital for providing quality online instruction in NMP. Respondents made it clear that cost of these resources would be an important consideration. Format would also be important because it seemed apparent, based on written responses, that multimedia resources for NMP should be organized by topic to facilitate incorporation into classroom lectures.

In light of recent shifts in organizational structure in departments that contain horticulture programs as well as the current availability of and ease associated with using technology to provide instruction in a variety of formats, opportunities exist to create new and innovative methods 
for instructional delivery in NMP courses. Even when traditional NMP courses are discontinued or departmental emphasis shifts away from this traditional horticultural topic, instruction could still be provided to undergraduate students through distance and online formats. Ideally, a series of instructional videos in NMP, arranged by topic, implemented in NMP and other courses throughout the country, could increase exposure to and understanding of an agricultural industry that continues to grow and be profitable.

Although some NMP courses have been eliminated within the United States, content tends to be similar among departments, and enrollment remains consistent. In general, faculty indicate a willingness to incorporate the use of multimedia resources into classroom instruction and in many cases have already done so. Although instructors would not intend to replace all traditional nursery field trips with virtual ones, there was general agreement that a virtual format could supplement existing field trips and would increase the number of operations students could view, even if it was not in person.

\section{Literature cited}

American Nurseryman. 2010. American Nurseryman. 6 Apr. 2010. <http:// www.amerinursery.com/Shop/tabid/ 54/Default.aspx>.

Basinger, A.R., C.B. McKenney, and D. Auld. 2009. Competencies for a United States horticulture undergraduate major: A national Delphi study. HortTechnology 19:452-458.

Belanger, Y. 2005. Duke University iPod first year experience final evaluation report. 11 Dec. 2006. <http://cit.duke.edu/ pdf/ipod_initiative_04_05.pdf>.
Brunner, J.S. 1961. The process of education. Harvard Universiy Press, Cambridge, MA.

Chinney, G.M. 2006. Emerging technologies going to the mall: Mobile assisted language learning. Lang. Learn. Technol. 10:9-16.

Cofield, J.L. 2002. An assessment of streaming video in web-based instruction. Proc. Annu. Mtg. Mid-South Educ. Res. Assn, Chattanooga, TN. p. 43.

Corporation for Public Broadcasting. 1997. Study of school uses of television and video: 1996-1997 school year summary report. Corporation for Public Broadcasting, Publications, Washington, DC.

Dyer, J.E. and E. Osborne. 1996. Effects of teaching approach on achievement of agriculture education students with varying learning styles. J. Agr. Educ. 37:4351 .

Gomez, N. 2004. Is an instructional video better than a face-to-face demo to teach T-budding in an intro plant propagation course? HortTechnology 14:619-621.

Harkess, R.L., M.R. Evans, T. Cavins, J.S. Kuehny, and L. Greer. 2007. Virtual field trips: Expanding the greenhouse classroom. Acta Hort. 762:439-443.

Insight Media. 2010. Container grown plants. U.S. Customers $>$ Subject $>$ Agriculture > Plant, Crop, \& Soil Sci. 6 Apr. 2010. <http://www.insight-media. com/IMHome.asp >.

Jerardo, A. 2007. Floriculture and nursery crops yearbook. 6 Apr. 2010. <http:// www.ers.usda.gov/Publications/Flo/ 2007/09Sep/FLO2007.pdf>.

Krepel, W.J. and C.R. DuVall. 1981. Field trips: A guide for planning and conducting educational experiences. Natl. Educ. Assn. Distribution Center, Westhaven, CT.

Larkin-Hein, T. and D.A. Zollman. 2000. Digital video, learning styles, and student understanding of kinematics graphs. J. SMET (Science, Math, Engineering, Technology). Educ.: Innovations Res. 1: 17-30.

Lin, L.Y. and T. Fox. 1999. A study of motivational effects and related student perceptions of skills improvement attained through the use of variously captioned authentic video materials. U.S. Dept. Educ., ERIC Doc. Reproduction Serv. \#ED467254.

Migliacci, N. 2002. New ways of using video technology in English language teaching. ESL (English as a Second Language). Mag. 5:22-24.

O'Connor, P. 2008. Oregon's nursery industry: A history of growth. 27 Jan. 2009. <http://www.qualityinfo.org $>$.

San Luis Video Publishing. 2010. Horticulture and agriculture DVDs. 6 Apr. 2010. <http://www.horticulturevideos.com/ horticulture.html\#introgreenmgmt>.

Sorrell, J.M. and P.R. Cangelosi. 2002. Teaching nursing research: Use of a research video to enhance student's learning. Nurs. Educ. Perspect. 23:133-136.

Spicer, J.I. and J. Stratford. 2001. Student perceptions of a virtual field trip to replace a real field trip. J. Comput. Assist. Learn. 17:345-354.

Tignor, M.E., S.B. Wilson, G.A. Giacomelli, C. Kubota, E. Fitz-Rodriguez, T.A. Irani, E.B. Rhoades, and M.J. McMahon. 2007. Multi-institutional cooperation to develop digital media for interactive greenhouse education. HortTechnology 17:397-399.

U.S. Department of Agriculture. 2007. Nursery crops 2006 summary. U.S. Dept. Agr., Natl. Agr. Stat. Serv., Agr. Stat. Board, Washington, DC.

Xie, K. and M. Gu. 2007. Advancing cooperative extension with podcast technology. J. Ext. 45. 28 Jan. 2008. <http:// www.joe.org/joe/2007october/tt2. shtml>. 